Article

\title{
Interaction Effect between Physical Activity and the BDNF Val66Met Polymorphism on Depression in Women from the PISMA-ep Study
}

\author{
Juan Antonio Zarza-Rebollo 1,2, Esther Molina 2,3,*, Elena López-Isac 1,2 (D), Ana M. Pérez-Gutiérrez ${ }^{1,2}$, \\ Blanca Gutiérrez ${ }^{2,4} \mathbb{D}$, Jorge A. Cervilla ${ }^{2,4,5}$ and Margarita Rivera ${ }^{1,2}$
}

check for updates

Citation: Zarza-Rebollo, J.A.; Molina, E.; López-Isac, E.; Pérez-Gutiérrez, A.M.; Gutiérrez, B.; Cervilla, J.A.; Rivera, M. Interaction Effect between Physical Activity and the BDNF Val66Met Polymorphism on Depression in Women from the PISMA-ep Study. Int. J. Environ. Res. Public Health 2022, 19, 2068

https: / / doi.org/10.3390/ ijerph19042068

Academic Editor: Paul B. Tchounwou

Received: 31 December 2021

Accepted: 9 February 2022

Published: 12 February 2022

Publisher's Note: MDPI stays neutral with regard to jurisdictional claims in published maps and institutional affiliations.

Copyright: (C) 2022 by the authors. Licensee MDPI, Basel, Switzerland. This article is an open access article distributed under the terms and conditions of the Creative Commons Attribution (CC BY) license (https:// creativecommons.org/licenses/by/ $4.0 /)$.
1 Department of Biochemistry and Molecular Biology II, Faculty of Pharmacy, University of Granada, 18071 Granada, Spain; jazarza@ugr.es (J.A.Z.-R.); lopezisac@ugr.es (E.L.-I.); ampergut@correo.ugr.es (A.M.P.-G.); mrivera@ugr.es (M.R.)

2 Institute of Neurosciences, Biomedical Research Centre, University of Granada, 18016 Granada, Spain; blancag@ugr.es (B.G.); jcervilla@ugr.es (J.A.C.)

3 Department of Nursing, Faculty of Health Sciences, University of Granada, 18071 Granada, Spain

4 Department of Psychiatry, Faculty of Medicine, University of Granada, 18016 Granada, Spain

5 Mental Health Service, University Hospital San Cecilio, 18016 Granada, Spain

* Correspondence: emrivas@ugr.es

\begin{abstract}
The relationship between depression and the Val66Met polymorphism at the brain-derived neurotrophic factor gene (BDNF), has been largely studied. It has also been related to physical activity, although the results remain inconclusive. The aim of this study is to investigate the relationship between this polymorphism, depression and physical activity in a thoroughly characterised sample of community-based individuals from the PISMA-ep study. A total of 3123 participants from the PISMAep study were genotyped for the BDNF Val66Met polymorphism, of which 209 had depression. Our results are in line with previous studies reporting a protective effect of physical activity on depression, specifically in light intensity. Interestingly, we report a gene-environment interaction effect in which Met allele carriers of the BDNF Val66Met polymorphism who reported more hours of physical activity showed a decreased prevalence of depression. This effect was observed in the total sample $(\mathrm{OR}=0.95,95 \% \mathrm{CI}=0.90-0.99, p=0.027)$ and was strengthened in women $(\mathrm{OR}=0.93$, $95 \% \mathrm{CI}=0.87-0.98, p=0.019)$. These results highlight the potential role of physical activity as a promising therapeutic strategy for preventing and adjuvant treatment of depression and suggest molecular and genetic particularities of depression between sexes.
\end{abstract}

Keywords: depression; physical activity; BDNF; Val66Met; rs6265

\section{Introduction}

Depression is a major public health problem, affecting more than 264 million people worldwide, with a higher prevalence in women. It is a leading cause of disease burden and years of disability [1,2], and is also associated with excess mortality [3]. Even though novel pharmacological choices have arisen in the past decades, there still remains a lack of efficiency in pharmacological treatment. In this aspect, there is a rate of non-response to the first election of up to two-thirds of the patients, and between $15-33 \%$ in multiple interventions [4]. Therefore, the use of antidepressants has prompted a long-standing debate regarding their effectiveness compared to placebo [5,6]. In an extensive metaanalysis of published and unpublished clinical trials, a small drug-placebo difference directly related to the initial severity of depression was reported [7].

Consequently, novel approaches, such as physical activity, have emerged as potential therapeutic strategies, with a promising effect both decreasing the symptomatology of depression [7,8], and in its prevention [9-11]. Remarkably, among other variables, it is plausible that sex may have a differential role in the impact of physical activity on 
depression, according to different studies. In this regard, it has been reported that physical activity leads to more extensive benefits on executive processes in women than in men in a healthy population [12]. These differences remain unclear when a population with depression is considered. Some studies have reported greater differences in the relationship between physical activity and the improvement in depressive symptoms in men $[13,14]$, whereas others have reported similar results in women [15-17]. Nonetheless, recent studies with extensive samples and meta-analyses did not find that these differences between sexes were statistically significant [18-20].

One of the mechanisms suggested to be involved in the relationship between depression and the practice of physical activity is the brain-derived neurotrophic factor (BDNF), a neurotrophin related to key brain processes at molecular and functional stages, such as growth and survival of neurons [21], learning and memory [22]. The practice of physical activity has been associated with an increase of BDNF and genetic expression profiles promoting brain plasticity in animal models [23], with similar results in humans (for a review, see [24]). In this respect, current literature points towards a transient increase in peripheral BDNF concentrations after acute aerobic exercise, but not after strength exercise [25], and also an increase in resting concentrations of this neurotrophin after interventions with aerobic-but not resistance-physical activity [26]. Nonetheless, a recent meta-analysis of exercise interventions in depression was not able to extract any conclusive results from the available literature, highlighting the diversity of the studies included in the systematic review [27].

The Val66Met polymorphism, also known as rs6265, is a functional polymorphism within the promoter of the BDNF gene. The Met allele of this polymorphism has been associated with impaired regulation of secretion and intracellular trafficking of the BDNF protein in hippocampal neurons [28]. This risk allele has also been associated with modifying the protein function of BDNF in humans [29,30], and although it has been extensively studied in relation to depression and physical activity, the results remain inconclusive. The most recent meta-analyses investigating the association between depression and the Val66Met polymorphism found that this polymorphism does not confer risk for depression [31-33]. The effect of physical activity on serum BDNF has also been reported to depend on the Val66Met genotype, being that the difference in serum BDNF is significantly higher after physical activity exclusively in Val/Val participants [34,35]. However, this association could not be replicated in a subsequent study [36]. A more recent systematic review included studies assessing the association of this genotype with the effect of physical activity in diverse cognitive domains, concluding that the available evidence is too limited to draw conclusions [37]. Moreover, the association of this polymorphism as a mediator of the effect of physical activity on depressive symptoms has been assessed in several studies, also showing conflicting results. In a cross-sectional study comparing genetic susceptibility for depression between athletes and non-athletes, the Val/Val genotype was associated with a higher risk of reporting depressive symptoms only in non-athletes [38]. A recent observational study shows that physical activity moderates the association between depression and cognitive function, obtaining better results in different tasks in Met allele carriers [39]. In contrast, another observational study did not find a relationship between the Val66Met genotype, physical activity, and depressive symptoms [16]. Studies that included an intervention with physical activity in patients with depression have reported a greater decrease in depressive symptoms after the intervention, only in men with the Met allele of the Val66Met polymorphism [40], or in Met allele carriers who did not inform exposure to childhood adversity [41]. In adolescent women, a protective effect against depressive symptoms was found with higher levels of physical activity only in Met allele carriers [42]. Given the inconclusive results shown in the literature, we aim to investigate the involvement of the BDNF Val66Met polymorphism with depression and physical activity in a large sample of community-dwelling adults. 


\section{Materials and Methods}

\subsection{Study Design}

The PISMA-ep is a cross-sectional epidemiological study performed in a representative cohort of community-dwelling adults aiming to analyse the prevalence of psychiatric disorders and their correlates in Andalusia (south of Spain). The three main objectives of the PISMA-ep were: (1) to estimate the prevalence of common mental disorders in Andalusia, (2) to explore the associations existing between social, psychological and genetic factors with mental disorders, and (3) to gather data from an extensive cohort that could be used as the basis for further prospective studies. A more detailed description of the methodology and procedure of this study has been published elsewhere [43].

\subsection{Sample}

Randomly selected adults aged 18-75 years old living in all 8 provinces of Andalusia for at least a year were asked to participate in the PSIMA-ep study. We undertook a multistage sampling using different standard stratification levels utilizing a door-knocking approach. We excluded those individuals with an illness that precluded the completion of the interview, not speaking Spanish fluently, suffering from severe cognitive impairment or intellectual disability, and usually residing in an institution.

\subsection{Measures}

Neuropsychiatric measures: The DSM-IV diagnosis of major depression was ascertained using the Spanish version of the Mini-International Neuropsychiatric Interview (MINI) $[44,45]$. The MINI is a brief diagnostic structured interview that provides Axis I DSM-IV and ICD-10 compatible diagnoses for 16 mental disorders, including major depression. The MINI has obtained satisfactory psychometric properties, with good rates of validity and reliability on community-based populations [46,47]. This interview was conducted by a team of fully trained psychologists.

Anthropometric measures: For each participant, self-reported height and weight were obtained to calculate their body mass index (BMI) using the formula: weight in kilograms divided by height in meters squared $\left(\mathrm{kg} / \mathrm{m}^{2}\right)$. Participants were grouped into four categories, following WHO criteria [48]: underweight (BMI $<18.5 \mathrm{~kg} / \mathrm{m}^{2}$ ), normal weight (BMI 18.5-24.99 kg/m²), overweight (BMI $25.0-29.99 \mathrm{~kg} / \mathrm{m}^{2}$ ) and obesity $\left(\mathrm{BMI} \geq 30 \mathrm{~kg} / \mathrm{m}^{2}\right)$.

Physical activity: This information was gathered from a questionnaire including 3 questions about whether the participant practised any physical activity, the number of hours per week of physical activity and the intensity of the activity. The intensity was classified based on the Metabolic Equivalents of Task or METs (2 METs = two times the amount of oxygen consumed at rest) as light (<3 METs), moderate (3-5 METs) or vigorous ( $\geq 6 \mathrm{METs}$ )

Genotyping analysis: A biological sample was obtained from each participant with an Oragene ${ }^{\circledR}$ saliva DNA (OG-500; DNA Genotek Inc., Kanata, ON, Canada) collection kit. The Oragene ${ }^{\circledR}$ Saliva Collection Kit protocol was used for DNA extraction. The original DNA samples were prepared to be stored at $-80{ }^{\circ} \mathrm{C}$ in matrix plaque format. DNA quantification was measured using the Infinite ${ }^{\circledR}$ M200 PRO Multimode Microplate Reader (Tecan, Research Triangle Park, NC, USA). Genotyping of the BDNF Val66Met polymorphism was assessed using TaqMan ${ }^{\circledR}$ StepOnePlusTM Real-Time PCR System (Applied Biosystems, Foster City, CA, USA) following the manufacturer's instructions. The system software was used to analyse raw data.

\subsection{Statistical Analyses}

All statistical analyses were performed using R (version 4.0.3) [49]. The R package 'HardyWeinberg' was used to test Hardy-Weinberg equilibrium (HWE) and distribution of genotypes, both in the entire sample and in depression cases and controls, using Pearson's chi-squared tests [50,51]. 
We performed descriptive exploratory analyses to survey how dependent and independent variables were distributed and then explored univariable associations, considering parametric or non-parametric significance tests when required.

Logistic regression models were performed to explore the associations between: (1) physical activity variables (a. whether the participant practised physical activity, b. number of hours of physical activity and c. intensity of the activity) and depression and (2) the Val66Met genotype and depression. A dominant genetic model was assumed, due to the limited sample size. Finally, we assessed the interaction between the genetic (Val66Met genotype) and environmental (the practice of physical activity) variables, using multivariate logistic regression models. We estimated the probabilities for depression by combining the Val66Met genotype (Val/Val homozygous vs. Met allele carrier) and physical activity (binomial, number of hours or intensity). All the association and interaction analyses were performed both crudely and including sex, age and BMI as covariates.

\section{Results}

\subsection{Description of the Sample}

From the 4507 PISMA-ep total sample, 4286 (95.1\%) participants accepted to provide a saliva sample for the genetic studies. From those, 3194 (74.52\%) were genotyped for the $B D N F$ Val66Met polymorphism. A total of 71 (2.22\%) participants with BMI under 18.5 were excluded from the analyses. The final sample consisted of 3123 community-based adults, of which 209 were cases with depression (6.69\%) (Table 1).

Table 1. Summary of frequencies of independent variables.

\begin{tabular}{|c|c|c|c|}
\hline & Total Sample (3123) & Women 1554 (49.76\%) & Men 1569 (50.24\%) \\
\hline Mean age (s.d.) & $43.18(15.18)$ & $43.76(14.94)$ & $42.61(15.39)$ \\
\hline Mean BMI (s.d.) & $26.16(4.50)$ & $25.73(4.97)$ & $26.59(3.93)$ \\
\hline Diagnosis of depression & $\begin{array}{l}\text { No } 2914(93.31 \%) \\
\text { Yes } 209(6.69 \%)\end{array}$ & $\begin{array}{l}\text { No } 1406(90.48 \%) \\
\text { Yes } 148(9.52 \%)\end{array}$ & $\begin{array}{l}\text { No } 1508(96.11 \%) \\
\text { Yes } 61(3.89 \%)\end{array}$ \\
\hline Val66Met genotype & $\begin{array}{l}\text { ValVal } 1947(62.34 \%) \\
\text { ValMet } 1044(33.43 \%) \\
\text { MetMet } 132(4.23 \%)\end{array}$ & $\begin{array}{c}\text { ValVal } 969(62.36 . \%) \\
\text { ValMet } 512(32.95 \%) \\
\text { MetMet } 73(4.69 \%)\end{array}$ & $\begin{array}{c}\text { ValVal } 978(62.33 \%) \\
\text { ValMet } 532(33.91 \%) \\
\text { MetMet } 59(3.76 \%)\end{array}$ \\
\hline Met allele carrying & $1176(37.66 \%)$ & $585(37.64 \%)$ & $591(37.67 \%)$ \\
\hline Physical activity & $\begin{array}{l}\text { No } 1260(40.35 \%) \\
\text { Yes } 1863(59.65 \%)\end{array}$ & $\begin{array}{l}\text { No } 676(43.5 \%) \\
\text { Yes } 878(56.5 \%)\end{array}$ & $\begin{array}{l}\text { No } 584(37.22 \%) \\
\text { Yes } 985(62.78 \%)\end{array}$ \\
\hline $\begin{array}{l}\text { Mean hours of physical } \\
\text { activity (s.d.)* }\end{array}$ & $9.73(9.79)$ & $9.62(9.90)$ & $9.83(9.70)$ \\
\hline $\begin{array}{c}\text { Intensity of physical } \\
\text { activity }\end{array}$ & $\begin{array}{c}\text { No } 1260(40.35 \%) \\
\text { Light } 624(19.98 \%) \\
\text { Moderate } 988(31.64 \%) \\
\text { Vigorous } 251(8.04 \%)\end{array}$ & $\begin{array}{c}\text { No } 676(43.5 \%) \\
\text { Light } 350(22.52 \%) \\
\text { Moderate } 452(29.09 \%) \\
\text { Vigorous } 76(4.89 \%)\end{array}$ & $\begin{array}{c}\text { No } 584(37.22 \%) \\
\text { Light } 274(17.46 \%) \\
\text { Moderate } 536(34.16 \%) \\
\text { Vigorous } 175(11.15 \%)\end{array}$ \\
\hline
\end{tabular}

* Mean (s.d.) of reported hours of physical activity was calculated excluding participants reporting no physical activity.

The characteristics of the sample including the frequencies of the independent variables analysed, both genotypic (Val66Met polymorphism) and phenotypic (practice of physical activity, number of hours and intensity) are detailed in Table 1.

\subsection{The BDNF Val66Met Polymorphism and Depression}

There was no significant association between carrying the Met allele of the Val66Met polymorphism and depression, in the total sample in crude analyses nor after adjusting for sex, $\mathrm{BMI}$ and age $(\mathrm{OR}=1.04,95 \% \mathrm{CI}=0.77-1.39, p=0.81)$. Furthermore, these results were not significant neither in women $(\mathrm{OR}=1.05,95 \% \mathrm{CI}=0.73-1.50, p=0.78)$ nor in men $(\mathrm{OR}=1.01,95 \% \mathrm{CI}=0.59-1.70, p=0.974)$ after adjusting for age and BMI. The frequencies of the Val66Met genotypes are detailed in Table 2. 
Table 2. Associations between depression and genetic factors or physical activity variables. Statistically significant results are highlighted in bold.

\begin{tabular}{|c|c|c|c|c|c|c|c|c|c|}
\hline & \multicolumn{3}{|c|}{ Total Sample (3123) } & \multicolumn{3}{|c|}{ Women (1554) } & \multicolumn{3}{|c|}{ Men (1569) } \\
\hline & $\begin{array}{l}\text { Cases } \\
(209)\end{array}$ & $\begin{array}{l}\text { Controls } \\
\text { (2914) }\end{array}$ & $\begin{array}{l}\text { Adjusted * OR } \\
\quad(95 \% \mathrm{CI}), p\end{array}$ & $\begin{array}{l}\text { Cases } \\
(148)\end{array}$ & $\begin{array}{l}\text { Controls } \\
\text { (1406) }\end{array}$ & $\begin{array}{l}\text { Adjusted }{ }^{* *} \text { OR } \\
\quad(95 \% \mathrm{CI}), p\end{array}$ & Cases (61) & $\begin{array}{l}\text { Controls } \\
\text { (1508) }\end{array}$ & $\begin{array}{l}\text { Adjusted } * * \\
\text { OR }(95 \% C I), p\end{array}$ \\
\hline \multicolumn{10}{|c|}{ Genotypes } \\
\hline Val/Val & $130(62 \%)$ & $1817(62 \%)$ & & $92(62 \%)$ & $877(62 \%)$ & & $38(62 \%)$ & $940(62 \%)$ & \\
\hline Val/Met & $66(32 \%)$ & $978(34 \%)$ & $\begin{array}{c}0.98(0.71-1.33) \\
0.891\end{array}$ & $45(31 \%)$ & $467(33 \%)$ & $\begin{array}{c}0.96(0.65-1.40) \\
0.842\end{array}$ & $21(35 \%)$ & $511(34 \%)$ & $\begin{array}{c}1.02(0.58-1.75), \\
0.936\end{array}$ \\
\hline Met/Met & $13(6 \%)$ & $119(4 \%)$ & $\begin{array}{c}1.50(0.78-2.69) \\
0.195\end{array}$ & $11(7 \%)$ & $62(5 \%)$ & $\begin{array}{c}1.71(0.81-3.32) \\
0.131\end{array}$ & $2(3 \%)$ & $57(4 \%)$ & $\begin{array}{c}0.89(0.14-3.02) \\
0.876\end{array}$ \\
\hline \multicolumn{10}{|c|}{ Met allele carrying } \\
\hline Val/Val & $130(62 \%)$ & $1817(62 \%)$ & & $92(62 \%)$ & $877(62 \%)$ & & $38(62 \%)$ & $940(62 \%)$ & \\
\hline $\begin{array}{l}\text { Met allele } \\
\text { carriers }\end{array}$ & $79(38 \%)$ & $1097(38 \%)$ & $\begin{array}{c}1.04(0.77-1.39) \\
0.81\end{array}$ & $56(38 \%)$ & $529(38 \%)$ & $\begin{array}{c}1.05(0.73-1.50) \\
0.780\end{array}$ & $23(38 \%)$ & $568(38 \%)$ & $\begin{array}{c}1.01(0.59-1.70), \\
0.974\end{array}$ \\
\hline \multicolumn{10}{|c|}{ Physical activity } \\
\hline No & $111(53 \%)$ & $1149(39 \%)$ & & $83(56 \%)$ & $593(42 \%)$ & & $28(46 \%)$ & $556(37 \%)$ & \\
\hline Yes & $98(47 \%)$ & $1765(61 \%)$ & $\begin{array}{c}0.69(0.51-0.92) \\
0.011\end{array}$ & $65(44 \%)$ & $813(58 \%)$ & $\begin{array}{c}0.64(0.45-0.91) \\
0.013\end{array}$ & $33(54 \%)$ & $952(63 \%)$ & $\begin{array}{c}0.74(0.44-1.26) \\
0.26\end{array}$ \\
\hline \multicolumn{10}{|c|}{ Intensity of physical activity } \\
\hline No & $111(53 \%)$ & $1149(39 \%)$ & & $83(56 \%)$ & $593(42 \%)$ & & $28(46 \%)$ & $556(37 \%)$ & \\
\hline Light & $35(17 \%)$ & $589(21 \%)$ & $\begin{array}{c}0.59(0.39-0.87) \\
9.68 \times 10^{-3}\end{array}$ & $26(17 \%)$ & $324(23 \%)$ & $\begin{array}{c}0.57(0.35-0.89) \\
0.018\end{array}$ & $9(15 \%)$ & $265(18 \%)$ & $\begin{array}{c}0.64(0.28-1.32) \\
0.253\end{array}$ \\
\hline Moderate & $52(25 \%)$ & $936(32 \%)$ & $\begin{array}{c}0.73(0.51-1.04) \\
0.083\end{array}$ & $32(22 \%)$ & $420(30 \%)$ & $\begin{array}{c}0.65(0.41-1.00) \\
0.053\end{array}$ & $20(33 \%)$ & $516(34 \%)$ & $\begin{array}{c}0.85(0.46-1.55) \\
0.607\end{array}$ \\
\hline Vigorous & $11(5 \%)$ & $240(8 \%)$ & $\begin{array}{c}0.89(0.44-1.65) \\
0.734\end{array}$ & $7(5 \%)$ & $69(5 \%)$ & $\begin{array}{c}1.23(0.49-2.66) \\
0.630\end{array}$ & $4(6 \%)$ & $171(11 \%)$ & $\begin{array}{c}0.57(0.16-1.52) \\
0.307\end{array}$ \\
\hline \multicolumn{10}{|c|}{ Hours of physical activity } \\
\hline $\begin{array}{l}\text { Means expressed } \\
\text { in hours }\end{array}$ & $\begin{array}{c}\bar{x}=4.72 \\
\text { s.d. }=8.16\end{array}$ & $\begin{array}{c}\bar{x}=5.88 \\
\text { s.d. }=9.00\end{array}$ & $\begin{array}{c}0.99(0.97-1.01) \\
0.240\end{array}$ & $\begin{array}{c}\bar{x}=4.60 \\
\text { s.d. }=8.88\end{array}$ & $\begin{array}{c}\bar{x}=5.52 \\
\text { s.d. }=8.84\end{array}$ & $\begin{array}{c}0.99(0.97-1.01) \\
0.378\end{array}$ & $\begin{array}{c}\bar{x}=5.00 \\
\text { s.d. }=6.12\end{array}$ & $\begin{array}{c}\bar{x}=6.22 \\
\text { s.d. }=9.13\end{array}$ & $\begin{array}{c}0.98(0.95-1.01) \\
0.367\end{array}$ \\
\hline
\end{tabular}

Abbreviations: $\mathrm{CI}$, confidence interval; OR, odds ratio; $p, p$-value; $\bar{x}$, mean; s.d., standard deviation. ${ }^{*}$ Adjusted by age, BMI and sex. ${ }^{* *}$ Adjusted by age and BMI. Statistically significant results are highlighted in bold.

\subsection{Depression and Physical Activity}

We found a statistically significant protective effect against depression in those participants reporting any physical activity, which remained significant after adjusting for covariates (age and BMI), both in the total sample $(\mathrm{OR}=0.69,95 \% \mathrm{CI}=0.51-0.92, p=0.011)$ and in women $(\mathrm{OR}=0.64,95 \% \mathrm{CI}=0.45-0.91, p=0.013)$, but not in men $(\mathrm{OR}=0.74$, $95 \% \mathrm{CI}=0.44-1.26, p=0.26)$.

Regarding the intensity of physical activity, we found a protective effect for depression in those individuals who practiced light intensity (crude and after adjusting for sex, age and $\mathrm{BMI}$ ) and a trend association for those showing moderate intensity. However, no association with vigorous physical activity was found (light intensity: $\mathrm{OR}=0.59,95 \% \mathrm{CI}=0.39-0.87$, $p=9.68 \times 10-3$; moderate intensity: $\mathrm{OR}=0.73,95 \% \mathrm{CI}=0.51-1.04, p=0.083$; vigorous intensity: $\mathrm{OR}=0.89,95 \% \mathrm{CI}=0.44-1.65, p=0.734)$. We observed similar results in women (light intensity: $\mathrm{OR}=0.57,95 \% \mathrm{CI}=0.35-0.89, p=0.018$; moderate intensity: $\mathrm{OR}=0.65$, $95 \% \mathrm{CI}=0.41-1.00, p=0.053$; vigorous intensity: $\mathrm{OR}=1.23,95 \% \mathrm{CI}=0.49-2.66, p=0.630)$, but not in men (data shown in Table 2).

Finally, when we explored the effect of hours of physical activity on depression in the total sample, we did not find any association neither in crude analyses nor after adjusting for age, sex and BMI $(\mathrm{OR}=0.99,95 \% \mathrm{CI}=0.97-1.01, p=0.240)$. These results remained non-significant when women and men were analysed separately (data available in Table 2).

\subsection{The BDNF Val66Met Polymorphism and Physical Activity}

When exploring the association between Val66Met genotype and physical activity, we found a statistically significant association between practicing physical activity and carrying the Met allele. This association was found in the total sample $(\mathrm{OR}=1.26,95 \% \mathrm{CI}=1.08-1.47$, 
$p=0.002)$ and in men $(\mathrm{OR}=1.48,95 \% \mathrm{CI}=1.19-1.84, p=5.28 \times 10-4)$, but not in women. The association between carrying the Met allele and the intensity of physical activity was also assessed, but we did not find any significant effect, except for moderate physical activity only in males $(\mathrm{OR}=1.41,95 \% \mathrm{CI}=1.14-1.76, p=1.74 \times 10-3)$. Additionally, we did not find a significant association between hours of physical activity and carrying the Met allele in the total sample, nor in women or men. The associations between the BDNF Val66Met polymorphism and physical activity are shown in Supplementary Table S1.

\subsection{Interaction between the BDNF Val66Met Polymorphism, Depression and Hours of Exercise}

We found a significant interaction effect between the number of hours of physical activity and the risk for depression conferred by the Val66Met polymorphism (see Table 3 and Figure 1). Thereby, as the number of hours of exercise increases, the Met alleles carriers have a lower risk of depression compared to Val/Val homozygous. Those results remained statistically significant after adjusting for age, sex and BMI (OR = 0.95, 95\%CI = 0.90-0.99, $p=0.027)$ and was strengthened in women, also after adjusting for age and BMI (OR $=0.93$, $95 \% \mathrm{CI}=0.87-0.98, p=0.019)$. However, this interaction effect was not found in men.

Table 3. Interaction between Met allele carriers and physical activity variables on risk of depression. Statistically significant results are highlighted in bold.

\begin{tabular}{|c|c|c|c|c|}
\hline & & \multicolumn{3}{|c|}{ OR $(95 \% \mathrm{CI}), p$} \\
\hline & & Total Sample * & Women ** & Men ** \\
\hline \multicolumn{2}{|c|}{$\begin{array}{l}\text { Physical activity (yes } / \text { no) } \\
\text { carrying Met allele }\end{array}$} & $0.86(0.48-1.55), 0.616$ & $0.91(0.44-1.86), 0.786$ & $0.78(0.27-2.29), 0.641$ \\
\hline \multirow{4}{*}{$\begin{array}{c}\text { Intensity of } \\
\text { physical activity * } \\
\text { carrying Met allele }\end{array}$} & None & Ref. 1 & Ref. 1 & Ref. 1 \\
\hline & Light & $0.54(0.22-1.26), 0.167$ & $0.63(0.22-1.67), 0.363$ & $0.35(0.05-1.89), 0.257$ \\
\hline & Moderate & $0.94(0.46-1.90), 0.858$ & $1.07(0.43-2.60), 0.881$ & $0.73(0.21-2.46), 0.607$ \\
\hline & Vigorous & $2.00(0.54-8.31), 0.308$ & $1.15(0.22-6.64), 0.870$ & $\begin{array}{c}4.34(0.47-96.14) \\
0.234\end{array}$ \\
\hline \multicolumn{2}{|c|}{$\begin{array}{l}\text { Hours of physical activity * } \\
\text { carrying Met allele }\end{array}$} & $\begin{array}{c}0.95(0.90-0.99) \\
0.027\end{array}$ & $\begin{array}{c}0.93(0.87-0.98) \\
0.019\end{array}$ & $0.98(0.91-1.05), 0.648$ \\
\hline
\end{tabular}

Abbreviations: CI, confidence interval; OR, odds ratio; $p$, $p$-value. * Adjusted by age, BMI and sex. ${ }^{* *}$ Adjusted by age and BMI. Statistically significant results are highlighted in bold.
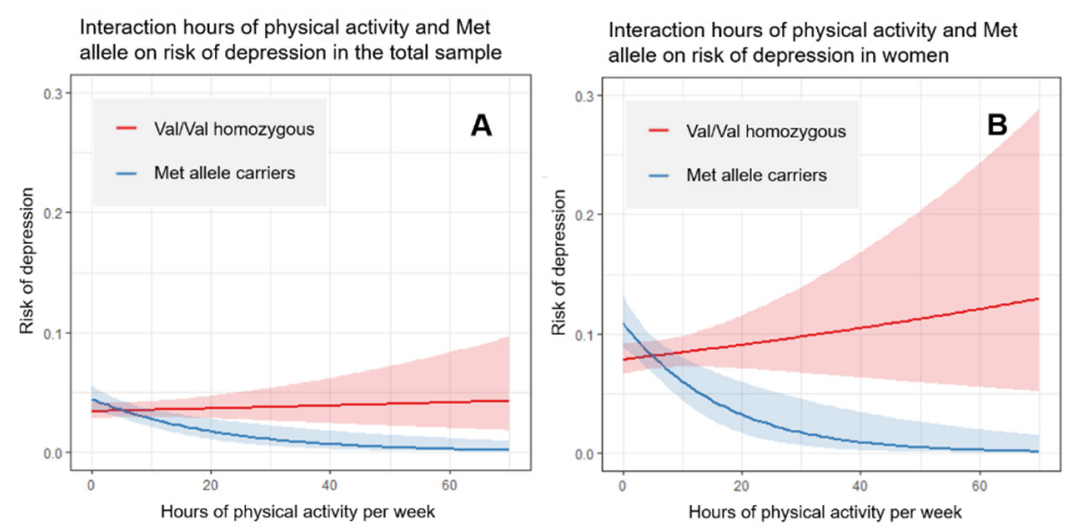

Figure 1. Graphic representation of the interaction between physical activity and the Met allele of the BDNF Val66Met polymorphism on the risk of depression, in (A) the total sample and (B) only in women. Results only in men were not statistically significant.

In contrast, when we assessed the binomial physical activity variable or the intensity of physical activity, no significant interactions were found (see Table 3). 


\section{Discussion}

The main aim of this study was to determine the potential role of the BDNF Val66Met polymorphism in the relationship between depression and physical activity in a large sample of community-based adults.

\subsection{The BDNF Val66Met Polymorphism and Depression}

We did not find a significant association between the BDNF Val66Met polymorphism and depression. This result is in line with the ones reported from previous studies, including extensive meta-analyses $[31,33]$. However, it has been suggested that more accurate assessments of the samples considering different parameters, such as sex, age, ethnicity and gene-gene interactions would be required in order to unveil the peculiarities of this relationship [52].

\subsection{Depression and Physical Activity}

In relation to physical activity, we found an association with a lower prevalence of depression. These results remained significant even after considering classical parameters involved in depression, i.e., sex and age, and also BMI, a variable linked to depression and physical activity [53]. Interestingly, in the PISMA-ep cohort, the prevalence of depression was significantly higher in those participants that reported no practice of physical activity versus those who practiced exercise. This effect was shown in the total sample and in women, but not in men. In this sense, multiple cross-sectional studies have shown significant associations between practicing physical activity and less prevalence of depression [54-56]. Moreover, prospective studies have described a significant effect of physical activity preventing the onset of depression. A systematic review [9] and a recent metaanalysis of prospective studies [10] have led to the conclusion that the practice of physical activity is associated with lower odds of incident depression. In their systematic review of prospective studies performed in the general population, Mammen and Faulkner observed in 25 out of 30 studies that reported physical activity at the beginning of the studies was inversely associated with incident depression at follow-up. Similarly, another recent metaanalysis reported an increased risk of developing depression when sedentary behaviour was higher [11]. These results support the effect observed in our cohort, which suggests a potential differential role of physical activity depending on the gender. Interestingly, four of these studies found this inverse association between practice of physical activity and incident depression at follow-up in women, but not in men [15,57-59]. Similarly, regarding the intensity of physical activity, we found significant differences in the prevalence of depression between participants who practiced light-intensity physical activity and the sedentary ones, suggesting a protective effect of physical activity, in the total sample and in women. This result is highly interesting, since the implication of light-intensity physical activity in depression has been less studied than moderate- and vigorous-intensity physical activity [60]. Our findings have important implications for public health, since they empathise that practicing light-intensity physical activity seems to have an important effect on depression. Light-intensity physical activity is well-accepted in general and clinical populations and it has properties that make it more transferable for certain population groups such as the elderly. In this sense, further research in this field should be encouraged.

Regarding high-intensity physical activity, we have previously reported a significant association with a lower prevalence of depression in an extended sample from the PISMAep cohort [61]. However, we could not find the same association here, possibly due to the smaller sample used in this study.

\subsection{The BDNF Val66Met Polymorphism and Physical Activity}

When we assessed the association between the Val66Met polymorphism and the practice of physical activity, we found a higher proportion of physically active participants among Met carriers, compared to homozygous Val/Val. Although this polymorphism might be one among many genetic variants influencing a complex behavioural outcome 
such as physical activity, it is worth highlighting this finding. There are few studies investigating this relationship, the majority reporting no association [62-65], whereas one study reported that Val/Val individuals experienced higher exertion than Met carriers, arguing that this could influence adherence to exercise [66]. Another study reported similar results regarding differences in intrinsic motivation during exercise in regular exercisers, finding greater intrinsic motivation in Met carriers compared to Val/Val participants [67]. This evidence makes us hypothesise that, if there is an effect, it could be mediated by intermediate factors.

\subsection{Interaction between the BDNF Val66Met Polymorphism, Depression and Hours of Exercise}

Interestingly, we found an interaction effect between the number of hours of physical activity and a decreased risk of depression, only in Met allele carriers. This interaction suggests that the practice of physical activity exerts a dose-dependent protective effect on the risk of depression, moderated by the BDNF Val66Met genotype. The practice of physical activity was significantly associated with less risk of depression in Met allele carriers but not in Val/Val homozygous. This effect was found in the total sample and was strengthened in women. These findings are similar to the results from previous research in healthy adolescent women, which reported an association between physical activity and the level of depressive symptoms, also moderated by the Val66Met genotype [42]. Similarly, they also found that women Met allele carriers who practiced physical activity were associated with lower depressive symptoms, compared to the Val/Val homozygous. This interaction could be explained under the hypothesis of differential susceptibility [68]. According to this, individuals with genetic susceptibility for a certain condition would be more malleable, i.e., would benefit more from a favourable environment. In this sense, risk allele carriers (Met allele), under beneficial conditions (practicing physical activity), would have less risk of depression than those without a certain genetic risk.

The reasons underlying sex differences in this interaction effect remain unclear, although it has been suggested that the social aspects of physical activity (e.g., being encouraged by others, practicing physical activity with family members) have a more beneficial effect on women than in men, and, consequently, this could possibly lead to the observation of less prevalence of depression in physically active women [55,69]. Another potential hypothesis to explain gender differences in the effect of physical activity in depressive symptoms in adults would be the role of oestrogen, which has a key role in physical activity and in mood. In this regard, a recent meta-analysis has reported that physical activity, even in light intensities, is associated with a reduction in depressive symptomatology in adult women of ages around the menopausal transition, repeatedly associated with increased risk of depressive symptoms [70].

In contrast, there is high heterogeneity in studies assessing the potential role of the $B D N F$ Val66Met polymorphism on the effect of physical activity on depression. For instance, one cross-sectional study evaluated the role of this polymorphism on the effect of self-reported physical activity on depressive symptoms (using the Center for Epidemiology Depression Scale) in a population-based cohort, not finding a statistically significant moderation effect, possibly due to the sample size [16]. Similar results were found in another study including a sample of 1196 adolescents [71]. Other studies have shown opposite results when comparing between endurance athletes $(n=55)$ and a control group $(n=58)$. The findings showed worse depressive symptoms in the control group participants that were Val/Val homozygous, whereas there were no differences when comparing genotypes in athletes [38]. In a cohort of US veterans, Pitts et al. suggested that the initially observed reduction in cognitive functioning associated with depression would be moderated both by the Val66Met polymorphism and by the practice of physical activity. Thus, in participants with depression, those who practiced physical activity outperformed their not physically active counterparts in different domains of cognition [39]. Interestingly, among Met allele carriers with depression, physically active participants scored better results in 
subjective cognition, visual learning and work memory tasks in comparison with physically inactive participants.

In experimental studies that analyse interventions with physical activity considering $B D N F$ Val66Met genotype, heterogeneous results have also been described. In a 12-week intervention in patients with depression, Rahman et al. observed that the highest proportion of responders to the intervention with physical activity (those who experimented a reduction greater than $50 \%$ on the Montgomery Asberg Depression rating scale) were Met allele carriers who were not exposed to childhood adversity, compared to Val/Val homozygous [41]. Furthermore, in a year-lasting intervention with physical activity (aerobic, strength, flexibility and balance training) performed in sedentary community-dwelling participants, Dotson et al. found a decrease in somatic symptoms of depression (one of the four factors of the Center for Epidemiologic Studies Depression Scale) which was more evident in Met allele carriers, but exclusively in men [40].

One strength of this study is the extensive and detailed characterization of our community sample. However, due to the cross-sectional design of the study, we are not able to establish causality, thus further longitudinal studies including larger sample sizes would be required. Furthermore, we are also aware that considering the assessment of physical activity compared to the accelerometer and objective measurements of physical activity, questionnaires may be influenced by the participant mood, recall bias and memory inaccuracy, and also social desirability bias [72]. Therefore, future studies should include additional objective measures for the assessment of physical activity.

Finally, further research would be required to assess whether the effect of physical activity on depression risk in longitudinal studies is moderated by the BDNF Val66Met genotype. In this way, we could consider using this polymorphism as a biological marker to predict the effect that physical activity would exert on depression risk. Furthermore, functional studies are necessary to investigate how the effect of physical activity on depression risk could be mediated by this polymorphism. In this regard, it has been hypothesised that the increase in BDNF caused by the practice of physical activity could partially be implied from a decrease in the hippocampal atrophy, therefore, protecting against depression [73].

\section{Conclusions}

In conclusion, our findings provide further evidence of a protective effect of physical activity on the risk of depression. We report a gene-environment interaction effect in which Met allele carriers of the BDNF Val66Met polymorphism who are more physically active showed a decreased prevalence of depression. Interestingly, this effect is strengthened in women, which has sex differences implications that should be addressed in future studies. Finally, these findings point to physical activity as a potential approach for the prevention of mental disorders in the general population and can also be considered as a non-invasive adjunct treatment for mental diseases.

Supplementary Materials: The following supporting information can be downloaded at: https: //www.mdpi.com/article/10.3390/ijerph19042068/s1, Table S1: Relationships between Val66Met genotype and physical activity variables.

Author Contributions: J.A.C. designed and coordinated the PISMA-ep study; J.A.C., M.R. and B.G. obtained the financial support for the project leading to this publication; M.R., E.M., B.G. and J.A.C. participated in the design of this study; M.R. and E.M. led the study and supervised the analyses; B.G. and E.M. contributed to the coordination and genotyping of the samples; J.A.C. helped with the phenotypic and clinical data; J.A.Z.-R. performed the analyses and wrote the first draft of the manuscript; A.M.P.-G. and E.L.-I. helped with the statistical analyses. All authors discussed the results, provided critical feedback, and approved the submission. All authors were involved in drafting the manuscript or revising it critically for important intellectual content. All authors have read and agreed to the published version of the manuscript. 
Funding: This study was partially funded by the Consejería de Salud, Junta de Andalucía (PI3222009), Consejería de Innovación, Proyecto de Excelencia (CTS-2010-6682), the Institute of Health Carlos III (Co-funded by European Regional Development Fund/European Social Fund “A way to make Europe" / "Investing in your future") (projects PI18/00238 and PI18/00467), the Marie Curie Research Grants Scheme (FP7 626235), and by a NARSAD Young Investigator Grant from the Brain \& Behavior Research Foundation (22514). Juan Antonio Zarza-Rebollo was supported by the Spanish Ministry of Economy and Competitiveness (BES-2017-082698). Elena López-Isac received financial support from the Spanish Ministry of Science and Innovation Juan de la Cierva Incorporación Program (grant code IJC2019-040080-I / AEI / 10.13039/501100011033). Ana M Pérez-Gutiérrez was supported by a grant from the Ministry of Economy and Competitiveness and Institute of Health Carlos III (FI19/00228), and Margarita Rivera was supported by the Ministry of Economy and Competitiveness Ramón y Cajal Program (RYC-2014-15774).

Institutional Review Board Statement: The study was conducted in accordance with the Declaration of Helsinki, and approved by the Ethics Committee of University of Granada (C.0003663, 23 April 2010).

Informed Consent Statement: Informed consent was obtained from all participants involved in the study.

Data Availability Statement: The data presented in this study are available on request from the corresponding author. Data are not publicly available due to privacy and ethical policies.

Acknowledgments: This study was performed as part of the PhD thesis of Juan Antonio ZarzaRebollo, conducted within the Official Doctoral Programme in Biomedicine of the University of Granada, Spain.

Conflicts of Interest: The authors declare no conflict of interest. The funders had no role in the design of the study; in the collection, analyses, or interpretation of data; in the writing of the manuscript, or in the decision to publish the results.

\section{References}

1. WHO. Depression: Fact Sheet. Available online: https://www.who.int/news-room/fact-sheets/detail/depression (accessed on 30 November 2021).

2. James, S.L.; Abate, D.; Abate, K.H.; Abay, S.M.; Abbafati, C.; Abbasi, N.; Abbastabar, H.; Abd-Allah, F.; Abdela, J.; Abdelalim, A.; et al. Global, regional, and national incidence, prevalence, and years lived with disability for 354 diseases and injuries for 195 countries and territories, 1990-2017: A systematic analysis for the Global Burden of Disease Study 2017. Lancet 2018, 392, 1789-1858. [CrossRef]

3. Oude Voshaar, R.C.; Aprahamian, I.; Borges, M.K.; van den Brink, R.H.S.; Marijnissen, R.M.; Hoogendijk, E.O.; van Munster, B.; Jeuring, H.W. Excess mortality in depressive and anxiety disorders: The Lifelines Cohort Study. Eur. Psychiatry 2021, 64, e54. [CrossRef]

4. Little, A. Treatment-Resistant Depression. Am. Fam. Physician 2009, 80, 167-172.

5. Ioannidis, J.P. Effectiveness of antidepressants: An evidence myth constructed from a thousand randomized trials? Philos. Ethics Humanit. Med. 2008, 3, 14. [CrossRef]

6. Kirsch, I.; Deacon, B.J.; Huedo-Medina, T.B.; Scoboria, A.; Moore, T.J.; Johnson, B.T. Initial Severity and Antidepressant Benefits: A Meta-Analysis of Data Submitted to the Food and Drug Administration. PLoS Med. 2008, 5, e45. [CrossRef]

7. Schuch, F.B.; Vancampfort, D.; Richards, J.; Rosenbaum, S.; Ward, P.B.; Stubbs, B. Exercise as a treatment for depression: A meta-analysis adjusting for publication bias. J. Psychiatr. Res. 2016, 77, 42-51. [CrossRef] [PubMed]

8. Stubbs, B.; Vancampfort, D.; Hallgren, M.; Firth, J.; Veronese, N.; Solmi, M.; Brand, S.; Cordes, J.; Malchow, B.; Gerber, M.; et al. EPA guidance on physical activity as a treatment for severe mental illness: A meta-review of the evidence and Position Statement from the European Psychiatric Association (EPA), supported by the International Organization of Physical Therapists in Mental Health (IOPTMH). Eur. Psychiatry 2018, 54, 124-144. [CrossRef] [PubMed]

9. Mammen, G.; Faulkner, G. Physical Activity and the Prevention of Depression: A Systematic Review of Prospective Studies. Am. J. Prev. Med. 2013, 45, 649-657. [CrossRef]

10. Schuch, F.B.; Vancampfort, D.; Firth, J.; Rosenbaum, S.; Ward, P.B.; Silva, E.S.; Hallgren, M.; Ponce De Leon, A.; Dunn, A.L.; Deslandes, A.C.; et al. Physical Activity and Incident Depression: A Meta-Analysis of Prospective Cohort Studies. Am. J. Psychiatry 2018, 175, 631-648. [CrossRef]

11. Wang, X.; Li, Y.; Fan, H. The associations between screen time-based sedentary behavior and depression: A systematic review and meta-analysis. BMC Public Health 2019, 19, 1524. [CrossRef] [PubMed] 
12. Barha, C.K.; Davis, J.C.; Falck, R.S.; Nagamatsu, L.S.; Liu-Ambrose, T. Sex differences in exercise efficacy to improve cognition: A systematic review and meta-analysis of randomized controlled trials in older humans. Front. Neuroendocrinol. 2017, 46, 71-85. [CrossRef]

13. Herring, M.P.; Puetz, T.W.; O'Connor, P.J.; Dishman, R.K. Effect of Exercise Training on Depressive Symptoms Among Patients With a Chronic Illness: A Systematic Review and Meta-analysis of Randomized Controlled Trials. Arch. Intern. Med. 2012, 172, 101-111. [CrossRef] [PubMed]

14. Rethorst, C.D.; Wipfli, B.M.; Landers, D.M. The Antidepressive Effects of Exercise. Sports Med. 2009, 39, 491-511. [CrossRef] [PubMed]

15. Carroll, D.D.; Blanck, H.M.; Serdula, M.K.; Brown, D.R. Obesity, physical activity, and depressive symptoms in a cohort of adults aged 51 to 61. J. Aging Health 2010, 22, 384-398. [CrossRef] [PubMed]

16. Gujral, S.; Manuck, S.B.; Ferrell, R.E.; Flory, J.D.; Erickson, K.I. The BDNF Val66Met polymorphism does not moderate the effect of self-reported physical activity on depressive symptoms in midlife. Psychiatry Res. 2014, 218, 93-97. [CrossRef] [PubMed]

17. Zhang, J.; Yen, S.T. Physical Activity, Gender Difference, and Depressive Symptoms. Health Serv. Res. 2015, 50, 1550-1573. [CrossRef]

18. Chekroud, S.R.; Gueorguieva, R.; Zheutlin, A.B.; Paulus, M.; Krumholz, H.M.; Krystal, J.H.; Chekroud, A.M. Association between physical exercise and mental health in 1.2 million individuals in the USA between 2011 and 2015: A cross-sectional study. Lancet Psychiatry 2018, 5, 739-746. [CrossRef]

19. Conn, V.S. Depressive Symptom Outcomes of Physical Activity Interventions: Meta-analysis Findings. Ann. Behav. Med. 2010, 39, 128-138. [CrossRef]

20. Gordon, B.R.; McDowell, C.P.; Hallgren, M.; Meyer, J.D.; Lyons, M.; Herring, M.P. Association of Efficacy of Resistance Exercise Training With Depressive Symptoms. JAMA Psychiatry 2018, 75. [CrossRef]

21. Cowansage, K.K.; LeDoux, J.E.; Monfils, M.-H. Brain-Derived Neurotrophic Factor: A Dynamic Gatekeeper of Neural Plasticity. Curr. Mol. Pharmacol. 2010, 3, 12-29. [CrossRef]

22. Ahlskog, J.E.; Geda, Y.E.; Graff-Radford, N.R.; Petersen, R.C. Physical Exercise as a Preventive or Disease-Modifying Treatment of Dementia and Brain Aging. Mayo Clin. Proc. 2011, 86, 876-884. [CrossRef] [PubMed]

23. Cotman, C.W.; Berchtold, N.C. Exercise: A behavioral intervention to enhance brain health and plasticity. Trends Neurosci. 2002, 25, 295-301. [CrossRef]

24. Voss, M.W.; Vivar, C.; Kramer, A.F.; van Praag, H. Bridging animal and human models of exercise-induced brain plasticity. Trends Cogn. Sci. 2013, 17, 525-544. [CrossRef] [PubMed]

25. Knaepen, K.; Goekint, M.; Heyman, E.M.; Meeusen, R. Neuroplasticity-Exercise-Induced Response of Peripheral Brain-Derived Neurotrophic Factor. Sports Med. 2010, 40, 765-801. [CrossRef] [PubMed]

26. Dinoff, A.; Herrmann, N.; Swardfager, W.; Liu, C.S.; Sherman, C.; Chan, S.; Lanctôt, K.L. The Effect of Exercise Training on Resting Concentrations of Peripheral Brain-Derived Neurotrophic Factor (BDNF): A Meta-Analysis. PLoS ONE 2016, 11, e0163037. [CrossRef] [PubMed]

27. Dinoff, A.; Herrmann, N.; Swardfager, W.; Gallagher, D.; Lanctôt, K.L. The effect of exercise on resting concentrations of peripheral brain-derived neurotrophic factor (BDNF) in major depressive disorder: A meta-analysis. J. Psychiatr. Res. 2018, 105, 123-131. [CrossRef]

28. Egan, M.F.; Kojima, M.; Callicott, J.H.; Goldberg, T.E.; Kolachana, B.S.; Bertolino, A.; Zaitsev, E.; Gold, B.; Goldman, D.; Dean, M.; et al. The BDNF val66met Polymorphism Affects Activity-Dependent Secretion of BDNF and Human Memory and Hippocampal Function. Cell 2003, 112, 257-269. [CrossRef]

29. Baj, G.; Carlino, D.; Gardossi, L.; Tongiorgi, E. Toward a unified biological hypothesis for the BDNF Val66Met-associated memory deficits in humans: A model of impaired dendritic mRNA trafficking. Front. Neurosci. 2013, 7, 188. [CrossRef] [PubMed]

30. Rybakowski, J.K. BDNF gene: Functional Val66Met polymorphism in mood disorders and schizophrenia. Pharmacogenomics 2008, 9, 1589-1593. [CrossRef] [PubMed]

31. Gyekis, J.P.; Yu, W.; Dong, S.; Wang, H.; Qian, J.; Kota, P.; Yang, J. No association of genetic variants in BDNF with major depression: A meta- and gene-based analysis. Am. J. Med. Genet. Part B Neuropsychiatr. Genet. 2013, 162, 61-70. [CrossRef]

32. Li, M.; Chang, H.; Xiao, X. BDNF Val66Met polymorphism and bipolar disorder in European populations: A risk association in case-control, family-based and GWAS studies. Neurosci. Biobehav. Rev. 2016, 68, 218-233. [CrossRef]

33. Verhagen, M.; van der Meij, A.; van Deurzen, P.A.M.; Janzing, J.G.E.; Arias-Vásquez, A.; Buitelaar, J.K.; Franke, B. Meta-analysis of the BDNF Val66Met polymorphism in major depressive disorder: Effects of gender and ethnicity. Mol. Psychiatry 2010, 15, 260-271. [CrossRef]

34. Lemos, J.R.; Alves, C.R.; de Souza, S.B.C.; Marsiglia, J.D.C.; Silva, M.S.M.; Pereira, A.C.; Teixeira, A.L.; Vieira, E.L.M.; Krieger, J.E.; Negrão, C.E.; et al. Peripheral vascular reactivity and serum BDNF responses to aerobic training are impaired by the BDNF Val66Met polymorphism. Physiol. Genom. 2016, 48, 116-123. [CrossRef] [PubMed]

35. Nascimento, C.M.C.; Pereira, J.R.; Pires de Andrade, L.; Garuffi, M.; Ayan, C.; Kerr, D.S.; Talib, L.L.; Cominetti, M.R.; Stella, F. Physical Exercise Improves Peripheral BDNF Levels and Cognitive Functions in Mild Cognitive Impairment Elderly with Different BDNF Val66Met Genotypes. J. Alzheimer's Dis. 2014, 43, 81-91. [CrossRef] [PubMed]

36. Helm, E.E.; Matt, K.S.; Kirschner, K.F.; Pohlig, R.T.; Kohl, D.; Reisman, D.S. The influence of high intensity exercise and the Val66Met polymorphism on circulating BDNF and locomotor learning. Neurobiol. Learn. Mem. 2017, 144, 77-85. [CrossRef] 
37. Liu, T.; Li, H.; Colton, J.P.; Ge, S.; Li, C. The BDNF Val66Met Polymorphism, Regular Exercise, and Cognition: A Systematic Review. West. J. Nurs. Res. 2020, 42, 660-673. [CrossRef]

38. Haslacher, H.; Michlmayr, M.; Batmyagmar, D.; Perkmann, T.; Ponocny-Seliger, E.; Scheichenberger, V.; Pilger, A.; Dal-Bianco, P.; Lehrner, J.; Pezawas, L.; et al. Physical exercise counteracts genetic susceptibility to depression. Neuropsychobiology 2015, 71, 168-175. [CrossRef] [PubMed]

39. Pitts, B.L.; Wen, V.; Whealin, J.M.; Fogle, B.M.; Southwick, S.M.; Esterlis, I.; Pietrzak, R.H. Depression and Cognitive Dysfunction in Older U.S. Military Veterans: Moderating Effects of BDNF Val66Met Polymorphism and Physical Exercise. Am. J. Geriatr. Psychiatry 2020, 28, 959-967. [CrossRef] [PubMed]

40. Dotson, V.M.; Hsu, F.C.; Langaee, T.Y.; McDonough, C.W.; King, A.C.; Cohen, R.A.; Newman, A.B.; Kritchevsky, S.B.; Myers, V.; Manini, T.M.; et al. Genetic Moderators of the Impact of Physical Activity on Depressive Symptoms. J. Frailty Aging 2016, 5, 6-14. [CrossRef]

41. Rahman, M.S.; Millischer, V.; Zeebari, Z.; Forsell, Y.; Lavebratt, C. BDNF Val66Met and childhood adversity on response to physical exercise and internet-based cognitive behavioural therapy in depressed Swedish adults. J. Psychiatr. Res. 2017, 93, 50-58. [CrossRef]

42. Mata, J.; Thompson, R.J.; Gotlib, I.H. BDNF genotype moderates the relation between physical activity and depressive symptoms. Health Psychol. 2010, 29, 130-133. [CrossRef] [PubMed]

43. Cervilla, J.A.; Ruiz, I.; Rodríguez-Barranco, M.; Rivera, M.; Ibáñez-Casas, I.; Molina, E.; Valmisa, E.; Carmona-Calvo, J.; MorenoKüstner, B.; Muñoz-Negro, J.E.; et al. Protocol and methodology of Study epidemiological mental health in Andalusia: PISMA-ep. Rev. Psiquiatr. Salud. Ment. 2016, 9, 185-194. [CrossRef] [PubMed]

44. MINI Entrevista Neuropsiquiátrica Internacional (Versión en Español 5.0. 0.) DSM-IV. Available online: http://www.acmcb.es/ files / 425-5332-DOCUMENT/MINI\%205\%20Entrevista_Neuropsiquiatrica_Internacional.pdf (accessed on 6 December 2021).

45. Sheehan, D.V.; Lecrubier, Y.; Sheehan, K.H.; Amorim, P.; Janavs, J.; Weiller, E.; Hergueta, T.; Baker, R.; Dunbar, G.C. The Mini-International Neuropsychiatric Interview (M.I.N.I.): The development and validation of a structured diagnostic psychiatric interview for DSM-IV and ICD-10. J. Clin. Psychiatry 1998, 59 (Suppl. 20), 22-33, quiz 34-57.

46. Otsubo, T.; Tanaka, K.; Koda, R.; Shinoda, J.; Sano, N.; Tanaka, S.; Aoyama, H.; Mimura, M.; Kamijima, K. Reliability and validity of Japanese version of the Mini-International Neuropsychiatric Interview. Psychiatry Clin. Neurosci. 2005, 59, 517-526. [CrossRef]

47. Rossi, A.; Alberio, R.; Porta, A.; Sandri, M.; Tansella, M.; Amaddeo, F. The reliability of the Mini-International Neuropsychiatric Interview-Italian version. J. Clin. Psychopharmacol. 2004, 24, 561-563. [CrossRef] [PubMed]

48. National Heart, Lung, and Blood Institute Classification of Overweight and Obesity by BMI, Waist Circumference, and Associated Disease Risks. Available online: https://www.nhlbi.nih.gov/health/educational/lose_wt/BMI/bmi_dis (accessed on 27 May 2021).

49. R Core Team. R: A Language and Environment for Statistical Computing; R Foundation for Statistical Computing: Vienna, Austria, 2020.

50. Graffelman, J. Exploring Diallelic Genetic Markers: The HardyWeinberg Package. J. Stat. Softw. 2015, 64, 1-23. [CrossRef]

51. Graffelman, J.; Camarena, J.M. Graphical Tests for Hardy-Weinberg Equilibrium Based on the Ternary Plot. Hum. Hered. 2008, 65, 77-84. [CrossRef]

52. Arosio, B.; Guerini, F.R.; Voshaar, R.C.O.; Aprahamian, I. Blood Brain-Derived Neurotrophic Factor (BDNF) and Major Depression: Do We Have a Translational Perspective? Front. Behav. Neurosci. 2021, 15, 5. [CrossRef]

53. Ströhle, A. Physical activity, exercise, depression and anxiety disorders. J. Neural. Transm. 2009, 116, 777-784. [CrossRef]

54. Asztalos, M.; De Bourdeaudhuij, I.; Cardon, G. The relationship between physical activity and mental health varies across activity intensity levels and dimensions of mental health among women and men. Public Health Nutr. 2010, 13, 1207-1214. [CrossRef]

55. Chipperfield, J.G.; Newall, N.E.; Chuchmach, L.P.; Swift, A.U.; Haynes, T.L. Differential Determinants of Men's and Women's Everyday Physical Activity in Later Life. J. Gerontol. Ser. B Psychol. Sci. Soc. Sci. 2008, 63, S211-S218. [CrossRef] [PubMed]

56. Stephens, T. Physical activity and mental health in the United States and Canada: Evidence from four population surveys. Prev. Med. 1988, 17, 35-47. [CrossRef]

57. Farmer, M.E.; Locke, B.Z.; Mościcki, E.K.; Dannenberg, A.L.; Larson, D.B.; Radloff, L.S. Physical activity and depressive symptoms: The nhanes i epidemiologic follow-up study. Am. J. Epidemiol. 1988, 128, 1340-1351. [CrossRef]

58. Mikkelsen, S.S.; Tolstrup, J.S.; Flachs, E.M.; Mortensen, E.L.; Schnohr, P.; Flensborg-Madsen, T. A cohort study of leisure time physical activity and depression. Prev. Med. 2010, 51, 471-475. [CrossRef]

59. Wang, F.; DesMeules, M.; Luo, W.; Dai, S.; Lagace, C.; Morrison, H. Leisure-time physical activity and marital status in relation to depression between men and women: A prospective study. Health Psychol. 2011, 30, 204-211. [CrossRef]

60. Felez-Nobrega, M.; Bort-Roig, J.; Ma, R.; Romano, E.; Faires, M.; Stubbs, B.; Stamatakis, E.; Olaya, B.; Haro, J.M.; Smith, L.; et al. Light-intensity physical activity and mental ill health: A systematic review of observational studies in the general population. Int. J. Behav. Nutr. Phys. Act. 2021, 18, 123. [CrossRef] [PubMed]

61. Porras-Segovia, A.; Rivera, M.; Molina, E.; López-Chaves, D.; Gutiérrez, B.; Cervilla, J. Physical exercise and body mass index as correlates of major depressive disorder in community-dwelling adults: Results from the PISMA-ep study. J. Affect. Disord. 2019, 251, 263-269. [CrossRef] [PubMed] 
62. Canivet, A.; Albinet, C.T.; André, N.; Pylouster, J.; Rodríguez-Ballesteros, M.; Kitzis, A.; Audiffren, M. Effects of BDNF polymorphism and physical activity on episodic memory in the elderly: A cross sectional study. Eur. Rev. Aging Phys. Act. 2015, 12, 15. [CrossRef] [PubMed]

63. Erickson, K.I.; Banducci, S.E.; Weinstein, A.M.; MacDonald, A.W.; Ferrell, R.E.; Halder, I.; Flory, J.D.; Manuck, S.B. The BrainDerived Neurotrophic Factor Val66Met Polymorphism Moderates an Effect of Physical Activity on Working Memory Performance. Psychol. Sci. 2013, 24, 1770-1779. [CrossRef]

64. Flack, K.; Pankey, C.; Ufholz, K.; Johnson, L.; Roemmich, J.N. Genetic variations in the dopamine reward system influence exercise reinforcement and tolerance for exercise intensity. Behav. Brain Res. 2019, 375, 112148. [CrossRef] [PubMed]

65. Watts, A.; Andrews, S.J.; Anstey, K.J. Sex Differences in the Impact of BDNF Genotype on the Longitudinal Relationship between Physical Activity and Cognitive Performance. Gerontology 2018, 64, 361-372. [CrossRef]

66. Bryan, A.; Hutchison, K.E.; Seals, D.R.; Allen, D.L. A transdisciplinary model integrating genetic, physiological, and psychological correlates of voluntary exercise. Health Psychol. 2007, 26, 30-39. [CrossRef] [PubMed]

67. Caldwell Hooper, A.E.; Bryan, A.D.; Hagger, M.S. What keeps a body moving? The brain-derived neurotrophic factor val66met polymorphism and intrinsic motivation to exercise in humans. J. Behav. Med. 2014, 37, 1180-1192. [CrossRef] [PubMed]

68. Belsky, J.; Pluess, M. Beyond diathesis stress: Differential susceptibility to environmental influences. Psychol. Bull. 2009, 135, 885-908. [CrossRef]

69. Teychenne, M.; Ball, K.; Salmon, J. Associations between physical activity and depressive symptoms in women. Int. J. Behav. Nutr. Phys. Act. 2008, 5, 27. [CrossRef] [PubMed]

70. Pérez-López, F.R.; Martínez-Domínguez, S.J.; Lajusticia, H.; Chedraui, P. Effects of programmed exercise on depressive symptoms in midlife and older women: A meta-analysis of randomized controlled trials. Maturitas 2017, 106, 38-47. [CrossRef]

71. Stavrakakis, N.; Oldehinkel, A.J.; Nederhof, E.; Oude Voshaar, R.C.; Verhulst, F.C.; Ormel, J.; de Jonge, P. Plasticity genes do not modify associations between physical activity and depressive symptoms. Health Psychol. 2013, 32, 785-792. [CrossRef]

72. Prince, S.A.; Adamo, K.B.; Hamel, M.; Hardt, J.; Connor Gorber, S.; Tremblay, M. A comparison of direct versus self-report measures for assessing physical activity in adults: A systematic review. Int. J. Behav. Nutr. Phys. Act. 2008, 5, 56. [CrossRef]

73. Erickson, K.I.; Miller, D.L.; Roecklein, K.A. The Aging Hippocampus: Interactions between Exercise, Depression, and BDNF. Neuroscientist 2012, 18, 82-97. [CrossRef] 